\title{
Development of tools for the automated analysis of spectra generated by tandem mass spectrometry
}

\author{
Sally Ellingson ${ }^{1}$, Joe Hughes ${ }^{2}$, Dylan Storey ${ }^{1 *}$, Rick Weber ${ }^{3}$, Nathan VerBerkmoes ${ }^{4}$ \\ From UT-ORNL-KBRIN Bioinformatics Summit 2010 \\ Cadiz, KY, USA. 19-21 March 2010
}

\section{Background}

While multiple tools exist for the analysis and identification of spectra generated in shotgun proteomics experiments, few easily implemented tools exist that allow for the automated analysis of the quality of spectra. A researcher's knowledge of the quality of a spectra from an experiment can be helpful in determining possible reasons for misidentification or lack of identification of spectra in a sample.

\section{Materials and methods}

We are developing a automated high throughput method that analyses spectra from 2d-LC-MS/MS datasets to determine their quality and overall determines the quality of the run. We will then compare our programs to existing programs that perform a similar function. Our program calculates a quality score based on the following metrics: signal/noise ratio, absolute signal intensity, peak number, predicted mass distances between peak, and percent of incoming mass accounted for by peaks. These scores are then graphed against the outputs of common database search algorithms in order to display the following four categories: High-quality/ Identified, High-quality/Unidentified, Low-quality/Identified, and Low-quality/Unidentified. We are currently testing the algorithm against 2d-LC-MS/MS runs of a mixed protein standard and blanks with no peptide spectra. The application samples are a time series of metaproteomes collected from environmental ground waters after biostimulation.

\footnotetext{
* Correspondence: dylan.storey@gmail.com

'Genome Sciences and Technology, University of Tennessee Knoxville, Knoxville, TN 37996, USA
}

\begin{abstract}
Author details
${ }^{1}$ Genome Sciences and Technology, University of Tennessee Knoxville, Knoxville, TN 37996, USA. ²Department of Ecology and Evolutionary Biology, University of Tennessee Knoxville, Knoxville, TN 37996, USA. ${ }^{3}$ Department of Electrical Engineering and Computer Science, University of Tennessee Knoxville, Knoxville, TN 37996, USA. ${ }^{4}$ Chemical Sciences Division, Oak Ridge National Lab, Oak Ridge TN 37831, USA.
\end{abstract}

Published: 23 July 2010

doi:10.1186/1471-2105-11-S4-P27

Cite this article as: Ellingson et al:: Development of tools for the automated analysis of spectra generated by tandem mass spectrometry. BMC Bioinformatics 2010 11(Suppl 4):P27.
Submit your next manuscript to BioMed Central and take full advantage of:

- Convenient online submission

- Thorough peer review

- No space constraints or color figure charges

- Immediate publication on acceptance

- Inclusion in PubMed, CAS, Scopus and Google Scholar

- Research which is freely available for redistribution

Submit your manuscript at www.biomedcentral.com/submit
C Biomed Central 